\title{
Augmented Reality Learning Media Based on Android for Sciences in Elementary Schools
}

\author{
Mita Septiani ${ }^{1}$, Mohammad Muhyidin Nurzaelani ${ }^{2}$, \\ Muhammad Iqbal Pahlevi ${ }^{3}$, Putri Eka Sevtiyuni ${ }^{4 *}$ \\ ${ }^{1}$ mita.septiani@uika-bogor.ac.id, Department of Education technology, Universitas Ibn Khaldun, Bogor, Indonesia. \\ ${ }^{2}$ m.muhyidin@uika-bogor.ac.id, Department of Education technology, Universitas Ibn Khaldun, Bogor, Indonesia. \\ ${ }^{3}$ iqbalpahlevi52@gmail.com, Department of Education technology, Universitas Ibn Khaldun, Bogor, Indonesia. \\ ${ }^{4}$ putrieka@ unsri.ac.id, Department of Information System, Computer Science Faculty, Universitas Sriwijaya, \\ Indonesia. \\ *Corresponding author: putrieka@unsri.ac.id
}

\begin{abstract}
This research aims to produce interactive learning media based on Augmented Reality (AR) that is appropriate for science subjects on material characteristics of the eight planets in the solar system. This research is a type of research and development (R\&D) using the ADDIE model, which includes the stages of Analysis, Design, Development, Implementation, and Evaluation. Respondents in this study were elementary students of class VI (six) in Pondok Rumput Elementary Bogor City. The data collection technique is distributing questionnaires to experts and students. Data analysis was performed with simple statistics and qualitative descriptive. The results showed that the Android-based AR learning media was appropriate to be used for science learning in elementary schools.
\end{abstract}

Keywords: learning media, Augmented Reality (AR), android, sciences

\section{INTRODUCTION}

Utilization of information and communication technologies such as Augmented Reality (AR) in learning can develop learners' skills. Information technology can help students in the development of all types of skills, both at the basic level and at the level of higher critical thinking skills [1]. Information technology-based learning media can function as a tool that can be used as an intermediary between teachers and students in understanding learning material more effectively and efficiently [2,3]

AR creates a layer of digital information above the physical world seen through an Android or iOS device [4]. Augmented reality (AR) can be defined as "a realworld context that is dynamically overlaid with coherent location or context-sensitive virtual information" [5]. Following that statement, AR can be used to visualize objects virtually into a real-world display, so AR can be used to help display objects that are difficult to display originally, such as in solar system learning. The ability of AR technology to display three-dimensional objects can be utilized to add a lot of information to the displayed object. The amount of nonverbal information related to verbal information obtained in the reading text will help the reader in understanding and receiving messages from the reading text [6]. AR has three main characteristics: (a) the combination of virtual objects and real objects in real settings (b) interacting people in real-time [7]

The use of AR technology is increasing in popularity in engineering [8], environmental science [9], and especially in education [10]. Currently, AR technology is used in every level of schooling, from K-12 [11, 12] to higher education [13]. The use of AR is very potential and interesting, inspires, and motivates students to explore and control from a variety of different perspectives that have never been considered in education [14].

Research has shown that AR technology can greatly improve educational outcomes [15]. For example, AR helps students to engage in authentic exploration in the real world [16]. AR allows us to experience scientific experiments, such as chemical reactions, which we cannot easily experience in the real world [5]. AR also makes it possible to visualize concepts such as airflow or magnetic fields, and also events, by displaying virtual elements on real objects [17]. AR helps students to improve their knowledge and skills and do it more effectively than other technologies [18]. This increases student motivation, and in this way, students gain better 
investigative skills and do not experience conceptual errors [19]

The material about Getting to Know the Solar System is in class VI in elementary school. This material has been compiled and is contained in the Electronic School Book (BSE) provided by the Ministry of Education and Culture. In its implementation in schools, this material is often felt difficult for students, especially in understanding the material about the characteristics of the planets. As we know, this series of planets in the solar system consisting of 9 planets makes it difficult for students to memorize and understand the characteristics of each planet, ranging from the characteristics of color, mass weight, orbit, to natural satellites that surround the planet. The lack of visualization of each planet, especially the illustration of images in most textbooks that look unclear, blurry, even colorless, also causes major problems, so students have difficulty understanding them. Another problem in implementing this learning material is the lack of teacher initiative in providing variations or appropriate learning methods to overcome the problems of the book, so students feel bored and less motivated to learn this material. Thus, the question of the problem in this study is what kind of learning media is appropriate for increasing students' understanding and motivation for learning in science subjects?

\section{RESEARCH METHODOLOGY}

This study uses a post-positivistic paradigm. Based on its purpose, research is included in research and development (R\&D) with the ADDIE (Analysis, Design, Development, Implementation, Evaluation) model. The study was conducted at Pondok Rumput Elementary School in Bogor City in June 2018 - August 2019. Data were collected by distributing questionnaires, interviews, observations, and documentation studies. The data that has been collected is then analyzed using simple statistics and qualitative descriptive.

\section{FINDING AND DISCUSSION}

The results of the study are described based on the ADDIE model.

Analysis

Based on the results of initial observations and interviews conducted by researchers obtained several conclusions as a basis for consideration or analysis of learning needs as follows. The results of the identification stage of the analysis of user needs are as follows:

1) The learning media must have an attractive visual appearance so that it is expected to be able to attract attention and increase the motivation to learn sixth-grade students in the material characteristics of the eight planets.

2) Learning media must be easily used by anyone, especially sixth-grade students at Pondok Rumput in Bogor City.

3) Learning media must be able to provide different learning experiences in Science subjects that have been given previously.

4) The learning objectives to be achieved are to describe the solar system, the sun as the center of the solar system, and the position and characteristics of solar system members.

\section{Design}

This learning media planning stage is divided into two stages, namely the technical specification analysis stage and the work analysis stage of the software application. The analysis of technical specifications has the aim to find out the minimum specifications of mobile phones or smartphones that can be used to run learning media applications that are developed smoothly and maximally. The minimum specifications for running this interactive learning media application are as follows.

Table 1. Minimum specifications for cellphones

\begin{tabular}{ll}
\hline Sistem Operasi $(O S)$ & Android 4.0 (Jelly Bean $)++$ \\
\hline$R A M$ & $1 \mathrm{~GB}$ \\
\hline Internal Memory & $500 \mathrm{MB}$ available \\
\hline Resolusi Layar & $\begin{array}{l}1.024 \times 768 \mathrm{px}(1.280 \times 720 \mathrm{px} \text { is the recommended } \\
\text { resolution })\end{array}$ \\
\hline Multimedia & Camera \\
\hline
\end{tabular}


The software that is used as the main program to create and develop interactive learning media is to use Unity3D and Vuforia. As for the supporting program for making interactive learning media, this is CorelDraw X7 with a 64-bit system for creating vector graphic images for the background and Augmented Reality card designs that will be integrated with this Augmented Reality interactive media. Researchers also use Adobe Photoshop CS6 with a 64-bit system to create and edit images on learning media. Media that have been developed will be used as a .apk file format, which will be exported in Vuforia.

The analysis phase of the work program is carried out to find out how they work on interactive learning media that has been made. The making of this interactive learning media aims to make it easier for users to learn material characteristics of the eight planets in the solar system. Users who, in this case, are students who use their mobile phones to scan the markers contained in the card against the Augmented Reality application so that 3-dimensional objects appear from each planet along with their explanations.

When the learning material has been compiled, then the next process is designing the program. The program design itself is a step used in developing an interactive learning media. There are two stages in program design, namely flowcharts, which explain the sequence of processes and the relationship between processes in detail in a program logically and the user interface design, which focuses more on the visual appearance of the learning media to be developed.

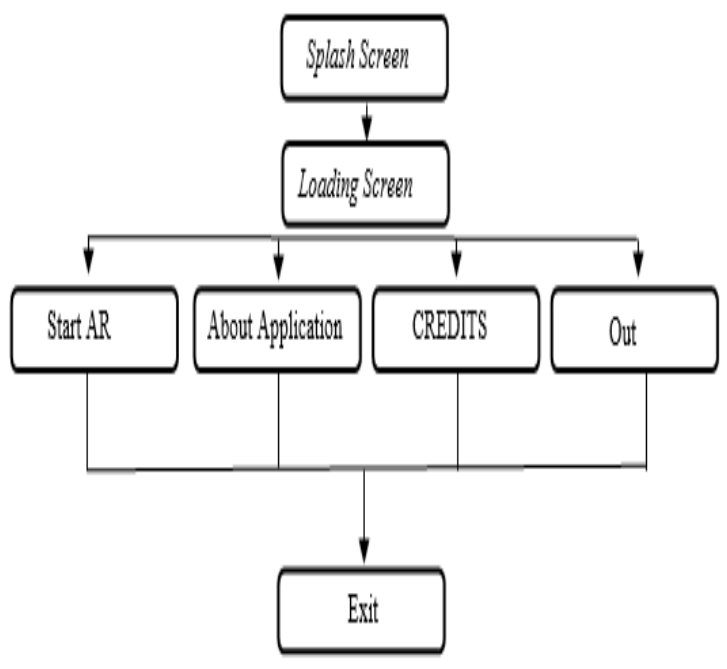

Figure 1. Media flow chart

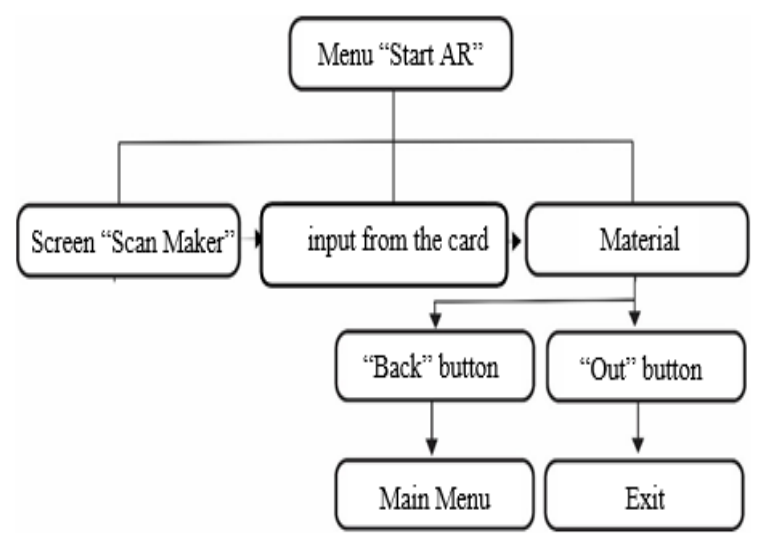

Figure 2. Menu flow chart

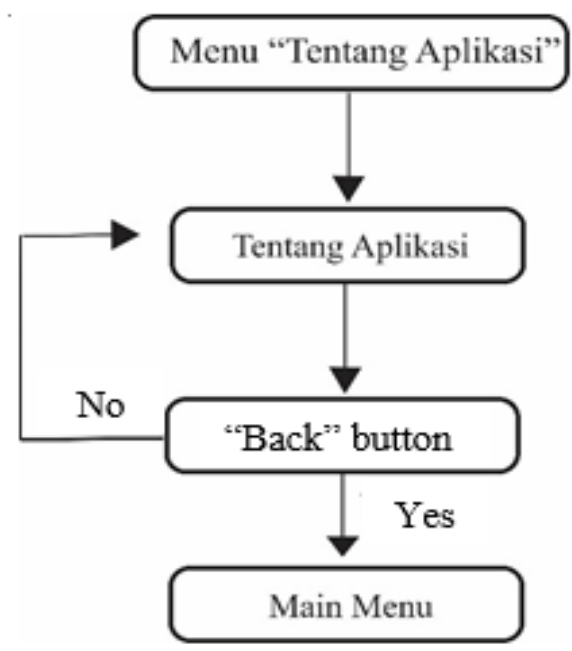

Figure 3. "Tentang Aplikasi” flow chart

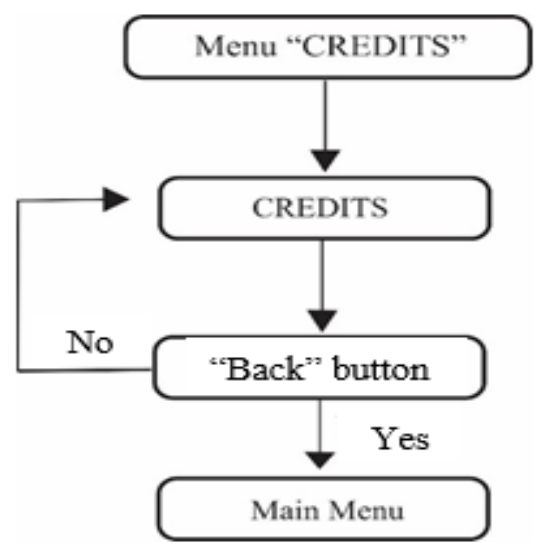

Figure 4. "Credits" flow chart 
The following table is the result of the development of the design that has been made.

Table 2. Media Development

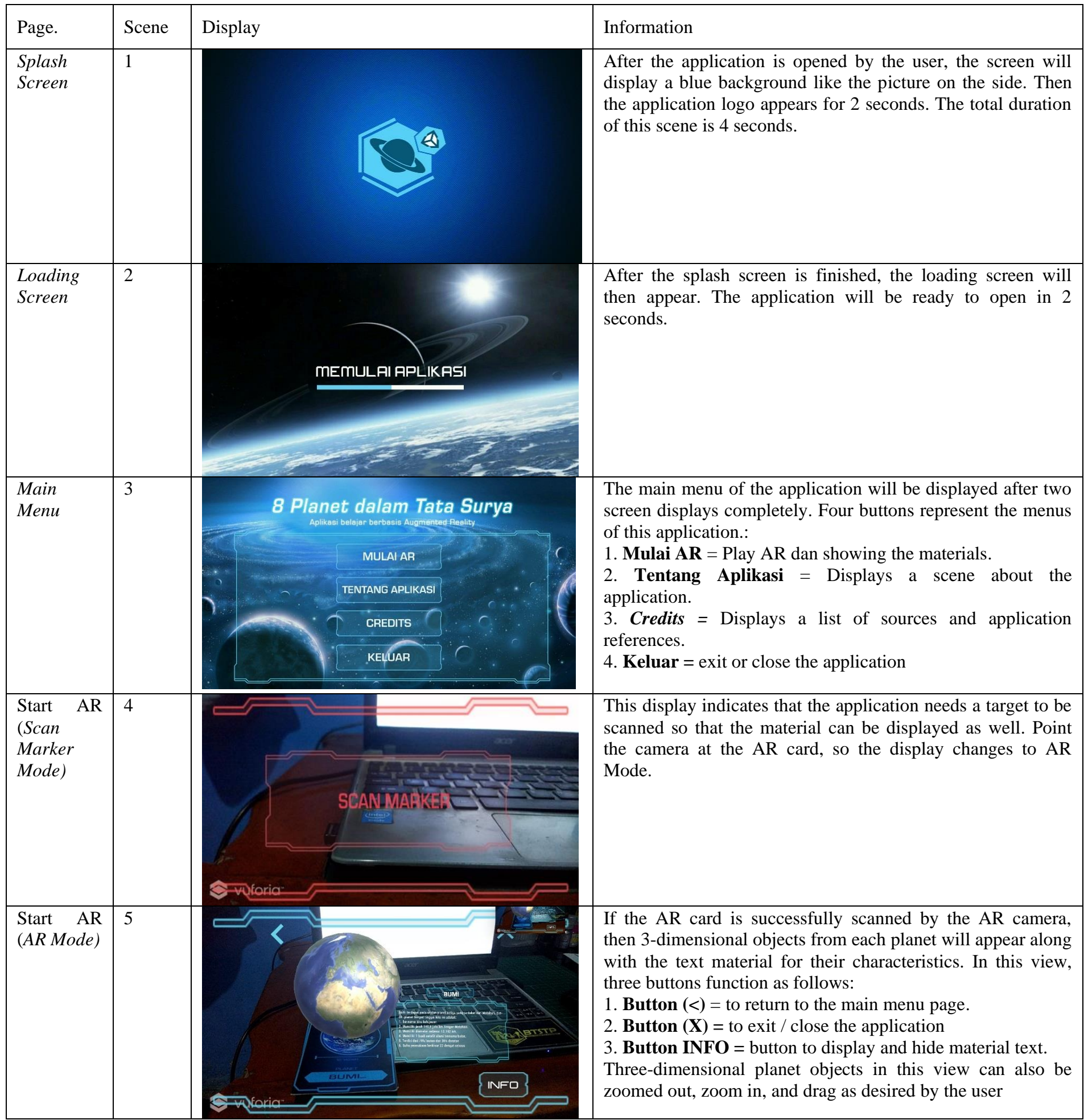




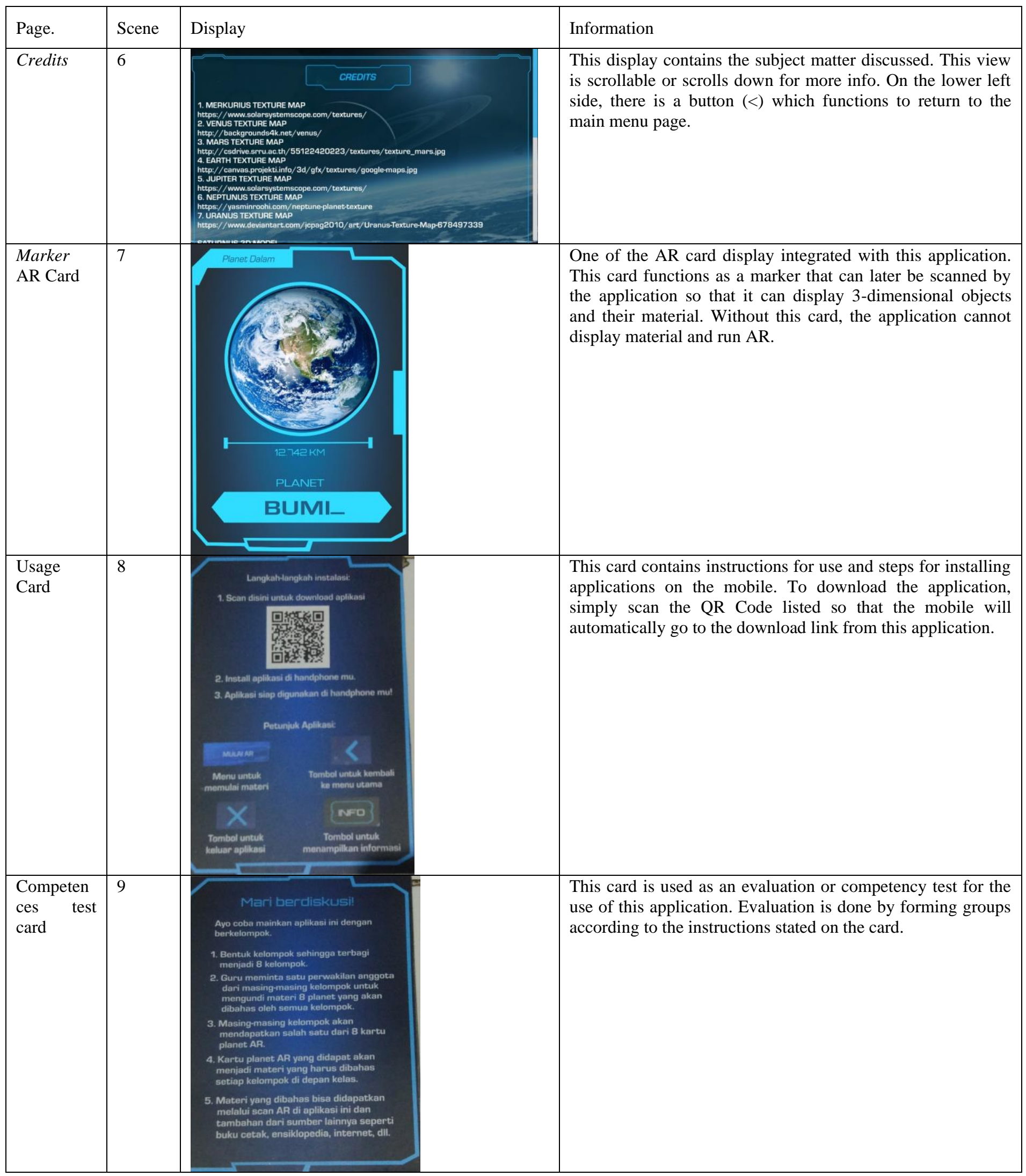




\section{IMPLEMENTATION}

Implementation of the interactive learning media program Augmented Reality material characteristics of the eight planets in the solar system is done by operating the program from beginning to end, then try each menu, function buttons, and scan markers so that $3 \mathrm{D}$ objects and materials can be displayed in the application.

The first step in implementing this interactive learning media is to open the application and run it using one cellphone. After the application is opened, a splash screen, loading screen, and main menu page will appear. From the main menu page, each menu is tested, starting from the AR Start menu, the About Application menu, the Credits menu, and the Exit menu. The details of the test work of learning media applications from the start page or splash screen page to the first menu page are: (1) testing the AR Start button. Next is the test on the marker mode scan page: (1) Test the scan marker from the AR card by pointing the camera towards the AR card. The tests on the AR Mode page consist of: (1) testing the info button, (2) testing out 3D planetary objects, (3) testing in 3D planetary objects, (4) testing dragging left, right, up, and down 3D planet object screen, (5) testing the back button to the main menu, (6) testing the application exit/closing button. Testing on the About Application menu are: (1) testing the screen scrolling function, (2) testing returning to the main menu. Tests on the Credits menu are: (1) testing the screen scrolling function, (2) testing the back button to the main menu. Tests on the Exit menu are: (1) testing the application exit button. Tests on the Usage card are (1) Testing a QR Code scan.

\section{EVALUATION}

Evaluation of learning media is from the results of oneto-one evaluation by experts (content experts, learning experts, media experts), one-to-one evaluation by students, and small groups by students. The following are the results of one-on-one evaluations conducted by experts. From the aspect of the suitability of the material, the material expert states that the material displayed in AR learning media is appropriate to use. From the aspect of learning design, instructional designer experts stated that AR learning media is feasible to be used with some improvement notes on the formulation of learning objectives. From the aspect of design, attractiveness, ease of use, and user interface, media experts stated that AR learning media is feasible to be used with some improvement notes on the display of the letters used. Next, the researchers revised by expert input.

The revised product was then tested on a one-to-one evaluation stage for three students. Students are selected based on the level of student ability, who have high, average, and low cognitive abilities. Judging from the attractiveness, ease of use, the material presented, and the user interface on AR learning media, it can be concluded that the media is suitable for use. There were some suggestions given by the students as material for the next revision, which is in the user interface section. The revised results were then tested on twenty students (small group evaluation). At this stage, it is seen how the use of AR media in learning and its interactions. The results of small group evaluations show that AR learning media increases student learning motivation and learning interaction in science subjects. With increased motivation, understanding, and higher involvement, it may increase the use of information and access to knowledge, improve digital and info-inclusion [20]. The combination of AR technology with educational content creates new types of automated applications and acts to enhance the effectiveness and attractiveness of teaching and learning for students in real-life scenarios [21]. The AR technology helps elementary school students to understand complex topics with digital experiments and visualization [22].

\section{CONCLUSION}

Augmented Reality interactive learning media based on Android material characteristics of eight planets in the solar system developed based on the ADDIE development model can facilitate teachers and students in learning activities at Pondok Rumput Elementary School, Bogor City. Learning is done with this media, especially for the subjects of Science Theme 9 (Nine) about Exploring the Solar System. This is based on the results of formative evaluations that have been carried out (one-to-one evaluation by experts, one-to-one evaluations by students, and small groups by students. Overall the Augmented Reality learning media based on Android material characteristics of the eight planets in the solar system can be said to be suitable for use in learning activities.

\section{REFERENCES}

[1] Mac Kinnon, Soledad. (2005). Technology Integration in the Classroom: Is There Only One Way to Make It Effective (http://www.techknowlogia.org).

[2] Fiedler, M., \& Haruvy, E. 2009. The lab versus the virtual $l a b$ and virtual field-An experimental investigation of trust games with communication. Journal of Economic Behavior and Organization. Vol. 72, No. 2, pp. 716-724. https://doi.org/10.1016/j.jebo.2009.07.013

[3] Morozov, M., Tanakov, A., Gerasimov, A., Bystrov, D., \& Cvirco, E. 2004. Virtual chemistry laboratory for school education. Proceedings-IEEE International Conference on Advanced Learning Technologies, 
ICALT, 31 Agustus - 1 September 2004. https://doi.org/10.1109/ICALT.2004.1357486

[4] Kroll (2016) in Wallace, H. 2018. Augmented Reality: Exploring Its Potential for Extension. Special Issue on Innovation 2018. Journal of Extension, September 2018. Volume 56. Number 5. Article \# 5FEA1

[5] Klopfer, E., \& Squire, K. (2008). Environmental detectives the development of an augmented reality platform for environmental simulations. Educational Technology Research and Development, 56(2), 203-228 [6] Idrus, A., \& Yudherta, A. (2016). Pengembangan Augmented Reality Sebagai Media dalam Meningkatkan Pemahaman Teks Bacaan. JTP - Jurnal Teknologi Pendidikan, 18(3), 144-155. https://doi.org/10.21009/JTP1803.3

[7] Azuma, R., Baillot, Y., Behringer, R., Feiner, S., Julier, S., \& MacIntyre, B. (2001). Recent advances in augmented reality. Computer Graphics and Applications, IEEE, 21(6), 34-47. http://dx.doi.org/10.1109/38.963459

[8] Behzadan, A. H., Dong, S., \& Kamat, V. R. (2015). Augmented reality visualization: a review of civil infrastructure system applications. Advanced Engineering Informatics, 29(2), 252-267.

[9] Tsai, M.-K., Lee, Y.-C., Lu, C.-H., Chen, M.-H., Chou, T.-Y., \& Yau, N.-J. (2012). Integrating geographical information and augmented reality techniques for mobile escape guidelines on nuclear accident sites. Journal of environmental radioactivity, 109, 36-44.

[10] Yen, J.-C., Tsai, C.-H., \& Wu, M. (2013). Augmented reality in the higher education: students' science concept learning and academic achievement in astronomy. Procedia-Social and Behavioral Sciences, 103, 165-173.

[11] Chiang, T. H., Yang, S. J., \& Hwang, G.-J. (2014b). Students' online interactive patterns in augmented reality-based inquiry activities. Computers \& Education, 78, 97-108.

[12] Kerawalla, L., Luckin, R., Seljeflot, S., \& Woolard, A. (2006). "Making it real": exploring the potential of augmented reality for teaching primary school science. Virtual Reality, 10(3-4), 163-174.

[13] Ferrer-Torregrosa, J., Torralba, J., Jimenez, M., García, S., \& Barcia, J. (2015). ARBOOK: development and assessment of a tool based on augmented reality for anatomy. Journal of Science Education and Technology, 24(1), 119-124.

[14] Andria. (2014). Pengembangan Buku Interaktif Berbasis Augmented Reality dengan smartphone Android. Jurnal Nasional Teknik Elektro dan Teknologi Informasi (JNTETI) 3.2, 2014.

[15] Chiu, J. L., DeJaegher, C. J., \& Chao, J. (2015). The effects of augmented virtual science laboratories on middle school students' understanding of gas properties. Computers \& Education, 85, 59-73.

[16] Dede, C. (2009). Immersive interfaces for engagement and learning. Science, 323(5910), 66-69.

[17] Dunleavy, M., Dede, C., \& Mitchell, R. (2009). Affordances and limitations of immersive participatory augmented reality simulations for teaching and learning. Journal of Science Education and Technology, 18(1), 722.

[18] El Sayed, N. A., Zayed, H. H., \& Sharawy, M. I. (2011). ARSC: augmented reality student card. Computers \& Education, 56(4), 1045-1061.

[19] Sotiriou, S., \& Bogner, F. X. (2008). Visualizing the invisible: augmented reality as an innovative science education scheme. Advanced Science Letters, 1(1), 114122.

[20] Coimbra, M. T., Cardoso, T., \& Mateus, A. (2015). Augmented reality: an enhancer for higher education students in math's learning?. Procedia Computer Science, 67, 332-339.

[21] Kesim, M., \& Ozarslan, Y. (2012). Augmented reality in education: current technologies and the potential for education. Procedia-Social and Behavioral Sciences, 47, 297-302.

[22] Lindner, C., Rienow, A., \& Jürgens, C. (2019). Augmented Reality applications as digital experiments for education-An example in the Earth-Moon System. Acta Astronautica, 161, 66-74 